\title{
Effect of dietary vegetable oils on milk yield, composition and CLA isomer profile in milk from dairy cows
}

\author{
F. Brzóska ${ }^{1}$ \\ National Research Institute of Animal Production, \\ Department of Animal Nutrition and Feed Science \\ 32-083 Balice, Poland
}

(Received 10 January 2005; revised version 18 March 2005; accepted 4 August 2005)

\begin{abstract}
The objective of this study was to determine the effect of adding vegetable oils (1.5\% DM) to dairy cow rations on the content of unsaturated fatty acids in milk, including CLA isomers. The experiment was conducted on 16 Red-and-White cows in $4 \times 4$ Latin square design. The cows were divided into four groups and fed rations composed of grass silage, maize silage, spent brewer's grain and concentrate.

No significant differences were found in milk yield or the amount of standardized fat and protein content milk (FPCM). The addition of linseed oil significantly increased the milk fat content, while sunflower oil, significantly decreased it. Cows given rapeseed or linseed oil produced more fat than in the remaining groups. No significant differences were found in the protein percentage of milk or in milk traits (acidity, coagulability, density) among groups.

Feeding cows rapeseed and sunflower seed oils increased the content of CLA isomers in milk by an average of $16 \%$. The highest content of cis-9 trans-11 CLA isomers was found in the milk of cows receiving sunflower seed oil, the lowest, linseed oil. The daily production of cis-9 trans-11 CLA in milk ranged from 8.8 to $10.5 \mathrm{~g} / \mathrm{d}$.
\end{abstract}

KEY WORDS: vegetable oils, cows, milk composition, fatty acids, CLA

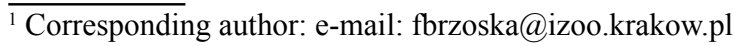




\section{INTRODUCTION}

The possibility that the composition of cow's milk can be modified through dietary interventions seems very promising (Thomas and Chamberlain, 1984). It has been found that humans can synthesize the long-chain fatty acids EPA and DHA from their precursors, linoleic and $\alpha$-linolenic acids, which are present in large amounts in rapeseed and soyabean oils. Both of these fatty acids inhibit HMG CoA reductase ( $\beta$-hydroxy- $\beta$-methylglutaryl-CoA) in the liver, the enzyme responsible for endogenous cholesterol synthesis in mammals. Unsaturated fatty acids are found in high amounts in oil seeds, especially in the seeds of evening primrose, linseed, sunflower, rapeseed, soyabean, whereas rich sources of EPA and DHA are fish meals and fish oil (Bartnikowska and Kulasek, 1994).

Much interest has arisen in the possibility of increasing the conjugated linoleic acid (CLA) content of milk. This acid has been called the "rumen acid". CLA has been found to have an anti-cancer effect in laboratory animals (NRC, 1996). Moreover, its cis-9 trans-11 CLA isomer has been associated with preventing heart disease and diabetes, modulating the immune system and reducing lipogenesis (Noone et al., 2002). It has been shown that grazing increases the CLA content of milk fat (Kelly et al., 1998; Dhiman et al., 1999), whereas feeding cows silage lowers it (White et al., 2001).

It can be supposed that feeding cows vegetable oils as a source of unsaturated fatty acids may intensify the hydrogenation of fatty acids, thus increasing the concentration of CLA and precursors of CLA isomers in rumen fluid. If it is assumed that part of the CLA and CLA isomer precursors are absorbed in the duodenum and small intestine, it would be possible for CLA to pass into the udder, thus increasing its content in milk. The products arising in the process of hydrogenating linoleic acid should increase the endogenous synthesis of CLA in the mammary gland and other tissues. The objective of the presented study was to test the above hypothesis.

\section{MATERIAL AND METHODS}

\section{Animals and feeding}

The study was conducted on 16 Red-and-White cows divided into 4 groups in $4 \times 4$ Latin square design with four 21-day periods each. The cows were selected for the experiment from a herd numbering 120 animals with an average milk yield of 6.5 thousand $\mathrm{kg}$ in the last lactation. The experimental cows produced from 24 to $25.5 \mathrm{~kg}$ milk/d between the $30^{\text {th }}$ and $60^{\text {th }}$ days of lactation. The ration was 
composed of maize and grass silages, wet spent brewer's grain, concentrate and vegetable oils mixed with wheat bran. The concentrate was fed during the morning and evening milkings at a dose of $0.28 \mathrm{~kg} / \mathrm{kg}$ obtained milk. At the same time the cows were given the vegetable oil. The grass and maize silages were fed after the morning milking, whereas the spent brewer's grain, in the afternoon before the evening milking. Meadow grass was cut for silage in the head emergence stage (the dominant grasses were Dactylis glomerata, Festuca pratensis, and Lolium perenne). Maize was harvested at the wax stage. The rations were supplemented with rapeseed oil (RPO) in the control group and linseed oil (LIO), soyabean oil (SYO) or sunflower oil (SFO) in the experimental groups. The oils were given in the amount of $320 \mathrm{~g}$ daily mixed with about $3.2 \mathrm{~kg}$ of wheat bran per cow. The concentrate was composed of crushed barley and wheat grain, rapeseed oilmeal and a premix. The cows were fed according to INRA standards (2001). Feed intake was monitored at the end of each experimental period.

\section{Measurements and chemical analysis}

Milk yield was measured in the last three days of each experimental period (Mini F.V. Milkometer, Tru-Test Distributors Ltd., New Zealand). Milk for determination of fat and protein contents was preserved by adding 2-bromo-2nitro-1,3-propanediol and frozen. Penicillin was added to the milk used for fatty acid determinations and frozen. Milk traits (acidity, density, specific gravity) were determined in fresh milk from milkings on the last day of each period.

Blood samples were drawn from the cow's jugular vein on the last day of the experiment after the morning milking. Glucose was determined in plasma $2 \mathrm{~h}$ after sampling, the remaining assays were performed on frozen samples.

The dry matter content, proximate analysis, calcium and phosphorous contents of feeds were determined by standard methods. The nutritional value of feeds and rations was calculated using WINWAR software, calcium was determined by atomic absorption spectrometry (ASA) using a Philips PU 9400 apparatus, phosphorous, by a colorimetric method according to Polish Standards (PN-76/R64781).

The fat and protein contents of milk were determined by NIR spectroscopy using a MilkoSkan model FT 120 from Foss-Electric. Acidity, density, and specific gravity of milk were assayed according to Polish Standards (PN-68/ A-86112). The nitrogen fraction in milk was determined using the procedure described by Gordon and Kolan (1983), milk fatty acids, as methyl esters, were analysed according to Atwal et al. (1990) using a gas chromatograph (GC Varian $3400)$ and a CP-Wax 58 column ( $60 \mathrm{~m} ; 0.53 \mathrm{~mm} ; 1.0$ micron). Fatty acids were esterified following the method described by Folch et al. (1956). 
The blood plasma contents of glucose, total protein, triglycerides, total cholesterol and high density lipoproteins (HDL) were determined enzymatically using diagnostic kits from Cormay Diagnostyka, whereas total lipids, using tests from Biochemtest.

The milk yield of cows was corrected for the content of fat (4\%) and protein (3.2\%); net energy intake (NEL) and protein digested in the intestine (PDI) were calculated. Milk production efficiency and the PDI-to-NEL ratio were calculated using regression equations (Subnel et al., 1994).

The results were subjected to statistical analysis of variance and a multiple range test (Tukey's test) using the Statgraphics 6.0 computer program.

\section{RESULTS}

The composition and nutritive value of the rations are given in Table 1 , whereas the fatty acid composition of the vegetable oils, in Table 2.

TABLE 1

Diet ingredients of cows, $\%$ DM

\begin{tabular}{lrrrr}
\hline & \multicolumn{4}{c}{ Plant oils } \\
\cline { 2 - 5 } Indices & $\begin{array}{r}\text { rapeseed } \\
\text { (RPO) }\end{array}$ & $\begin{array}{c}\text { linseed } \\
\text { (LIO) }\end{array}$ & $\begin{array}{c}\text { soyabean } \\
\text { (SYO) }\end{array}$ & $\begin{array}{c}\text { sunflower } \\
\text { (SFO) }\end{array}$ \\
\hline Diet components & & & & \\
grass silage & 30.75 & 28.06 & 28.66 & 28.24 \\
maize silage & 20.53 & 26.58 & 24.70 & 26.02 \\
brewery grain & 5.95 & 5.28 & 5.57 & 5.46 \\
wheat bran & 13.45 & 11.80 & 12.52 & 12.24 \\
plant oil & 1.50 & 1.50 & 1.50 & 1.50 \\
barley flacks & 14.22 & 13.58 & 13.75 & 13.44 \\
wheat flacks & 5.29 & 5.09 & 5.14 & 5.04 \\
rape oilmeal & 5.56 & 5.36 & 5.41 & 5.31 \\
limestone & 1.00 & 1.00 & 1.00 & 1.00 \\
dicalcium phosphate & 1.00 & 1.00 & 1.00 & 1.00 \\
salt & 0.25 & 0.25 & 0.25 & 0.25 \\
mineral-vitamin premix & 0.50 & 0.50 & 0.50 & 0.50 \\
& & & & \\
Nutrient content, \% DM & & & & \\
crude protein & 14.49 & 14.81 & 14.77 & 14.68 \\
ether extract & 4.89 & 4.75 & 4.82 & 4.91 \\
NDF & 45.84 & 42.30 & 43.51 & 43.12 \\
ADF & 20.31 & 20.42 & 21.05 & 20.78 \\
Ca & 0.87 & 0.87 & 0.85 & 0.86 \\
P & 0.45 & 0.44 & 0.44 & 0.45 \\
NEJ, MJ/kg & 6.90 & 6.97 & 6.90 & 6.90 \\
\hline
\end{tabular}


Adding vegetable oils to rations for cows in an amount approximately equivalent to $1.5 \%$ of the dry matter content of the ration $(320 \mathrm{~g} / \mathrm{d})$ did not significantly affect the intake of dry matter (Table 3), energy (NEL) or protein digested in the small intestine (PDI), hence there were no significant differences in milk yield or the amount of milk standardized for fat and protein content (FPCM).

TABLE 2

Fatty acid composition of plant oils, g/100 g

\begin{tabular}{lcccc}
\hline & \multicolumn{4}{c}{ Plant oils } \\
\cline { 2 - 5 } Item & $\begin{array}{c}\text { rapeseed } \\
(\mathrm{RPO})\end{array}$ & $\begin{array}{c}\text { linseed } \\
(\mathrm{LIO})\end{array}$ & $\begin{array}{c}\text { soyabean } \\
(\mathrm{SYO})\end{array}$ & $\begin{array}{c}\text { sunflower } \\
(\mathrm{SFO})\end{array}$ \\
\hline $\mathrm{C}_{14: 0}$ & 0.00 & 0.00 & 0.00 & 0.00 \\
$\mathrm{C}_{16: 0}$ & 4.04 & 4.48 & 10.22 & 6.22 \\
$\mathrm{C}_{16: 1}$ & 0.00 & 0.07 & 0.05 & 0,00 \\
$\mathrm{C}_{18: 0}$ & 1.50 & 3.85 & 4.56 & 3.99 \\
$\mathrm{C}_{18: 1}$ & 64.99 & 22.69 & 23.70 & 22.99 \\
$\mathrm{C}_{18: 2}$ & 19.58 & 17.47 & 53.99 & 64.13 \\
$\mathrm{C}_{18: 3}$ & 8.31 & 50.58 & 5.63 & 0.45 \\
$\mathrm{C}_{20: 0}$ & 0.00 & 0.00 & 0.00 & 0.00 \\
$\mathrm{C}_{20: 1}$ & 0.00 & 0.00 & 0.00 & 0.00 \\
$\mathrm{C}_{20: 4}$ & 0.00 & 0.00 & 0.00 & 0.00 \\
$\mathrm{C}_{20: 5}$ & 0.00 & 0.00 & 0.00 & 0.00 \\
$\mathrm{C}_{22: 6}$ & 0.00 & 0.00 & 0.00 & 0.00 \\
$\mathrm{SFA}_{\text {MUFA }}$ & 5.54 & 8.33 & 14.78 & 10.21 \\
$\mathrm{PUFA}_{\mathrm{M}}$ & 64.99 & 22.76 & 23.75 & 22.99 \\
$\mathrm{UFA}$ & 27.89 & 68.05 & 59.62 & 64.58 \\
PUFA/SFA & 11.7 & 2.7 & 1.6 & 2.3 \\
MUFA/PUFA & 5.0 & 8.2 & 4.0 & 6.3 \\
Sum & 2.3 & 0.3 & 2.5 & 0.4 \\
Other & 98.42 & 99.14 & 98.15 & 97.78 \\
\hline RPO - & 1.58 & 0.86 & 1.85 & 2.22 \\
\hline
\end{tabular}

RPO - rapeseed oil, LIO - linseed oil, SYO - soyabean oil, SFO - sunflower oil

Feeding cows linseed oil significantly increased the fat content of milk, whereas the addition of sunflower oil significantly lowered it $(\mathrm{P}<0.01)$. The differences in the protein content of milk did not reach statistical significance, with the exception of the cows given rapeseed oil $(\mathrm{P}<0.01)$. No significant differences were found in milk traits such as acidity, coagulability, density, or in milk production efficiency and the PDI/NEL ratio. The weight of the cows ranged from 575 to $599 \mathrm{~kg}$, and daily weight gains averaged $144.5 \mathrm{~g}$.

The $\mathrm{N}$ content of true protein, whey protein, and non-protein $\mathrm{N}$ was similar in all of the groups (Table 4), the casein $\mathrm{N}$ content was, however, significantly lower in cows fed rapeseed oil $(\mathrm{P}<0.01)$, and the share of casein $\mathrm{N}$ in total $\mathrm{N}$ was lower in the milk of cows given sunflower oil. 
TABLE 3

Feed intake, milk yield and milk nutrients content

\begin{tabular}{|c|c|c|c|c|c|}
\hline \multirow{2}{*}{ Item } & \multicolumn{4}{|c|}{ Plant oils } & \multirow{2}{*}{ SE } \\
\hline & RPO & LIO & SYO & SFO & \\
\hline \multicolumn{6}{|l|}{ Feed intake, $\mathrm{kg}$ of DM/d } \\
\hline total & 21.53 & 24.23 & 22.96 & 23.44 & 0.42 \\
\hline grass silage & 6.62 & 6.80 & 6.58 & 6.62 & 0.28 \\
\hline maize silage & 4.42 & 6.44 & 5.67 & 6.10 & 0.26 \\
\hline brewery grain & 1.28 & 1.28 & 1.28 & 1.28 & 0.01 \\
\hline wheat bran and plant oil & 3.22 & 3.26 & 3.22 & 3.22 & 0.01 \\
\hline concentrate & 5.99 & 6.49 & 6.21 & 6.22 & 0.09 \\
\hline \multicolumn{6}{|l|}{ Energy and protein intake } \\
\hline $\mathrm{NEL}, \mathrm{MJ} / \mathrm{d}$ & 79.82 & 77.50 & 75.46 & 75.18 & 1.50 \\
\hline IDP, $g / d^{1}$ & 1342.5 & 1290.0 & 1253.1 & 1255.8 & 25.5 \\
\hline \multicolumn{6}{|l|}{ Milk Production } \\
\hline milk, $\mathrm{kg} / \mathrm{d}$ & 25.54 & 24.60 & 24.23 & 24.71 & 0.46 \\
\hline FPCM, $\mathrm{kg} / \mathrm{d}$ & 25.24 & 24.53 & 23.92 & 23.80 & 0.46 \\
\hline fat, $\%$ & $3.84^{\mathrm{b}}$ & $3.98^{\mathrm{a}}$ & $3.87^{\mathrm{b}}$ & $3.80^{\mathrm{b}}$ & 0.05 \\
\hline fat, g/d & $975^{\mathrm{aA}}$ & $971^{\mathrm{aA}}$ & $931^{\mathrm{bB}}$ & $931^{\mathrm{bB}}$ & \\
\hline $\begin{array}{l}\text { protein, } \% \\
\text { protein } g / d\end{array}$ & $\begin{aligned} & 3.37 \\
859^{\mathrm{aA}} & \end{aligned}$ & $\begin{array}{r}3.35 \\
823^{\mathrm{bB}}\end{array}$ & $\begin{aligned} 3.36 \\
812^{\mathrm{bB}}\end{aligned}$ & $\begin{array}{l}3.30 \\
807^{\mathrm{bB}}\end{array}$ & 0.02 \\
\hline acidity, ${ }^{\circ} \mathrm{SH}$ & 6.65 & 6.55 & 6.45 & 6.31 & 15 \\
\hline renneting time, sec. & 164 & 129 & 138 & 149 & 0.07 \\
\hline density, $\mathrm{g} / \mathrm{cm}$ & 1.036 & 1.035 & 1.035 & 1.036 & 0.000 \\
\hline IDP/NEL-ratio & 16.88 & 16.66 & 16.65 & 16.68 & 0.14 \\
\hline \multicolumn{6}{|l|}{ Efficiency ${ }^{2}$} \\
\hline $\mathrm{LW}^{3}$ before experiment & 583.8 & 575.6 & 589.3 & 575.5 & \\
\hline LW after experiment & 599.2 & 594.3 & 590.2 & 589.0 & $\begin{array}{r}18.0 \\
0.6\end{array}$ \\
\hline $\mathrm{BM}$ change $\mathrm{e}^{4}, \mathrm{~g} / \mathrm{d}$ & +0.183 & +0.223 & +0.011 & +0.161 & \\
\hline
\end{tabular}

${ }^{1}$ intestine digestible protein (Subnel i in., 1994), ${ }^{2}$ efficiency for milk production (Subnel i in., 1994),

${ }^{3}$ liveweight, ${ }^{4}$ body mass, RPO - rapeseed oil, LIO - linseed oil, SYO - soyabean oil, SFO - sunflower oil, a,b values in the same rows with different letters differ significantly $(\mathrm{P}<0.05)$,

$A, B$ values in the same rows with different letters differ significantly $(\mathrm{P}<0.01)$

TABLE 4

$\mathrm{N}$-fraction in milk, $\mathrm{g} / 1000 \mathrm{ml}$

\begin{tabular}{lccccc}
\hline \multirow{2}{*}{ Item } & \multicolumn{5}{c}{ Plant oils } \\
\cline { 2 - 5 } & RPO & LIO & SYO & SFO & \\
\hline Total N & $5.28^{\mathrm{a}}$ & $5.25^{\mathrm{a}}$ & $5.27^{\mathrm{a}}$ & $5.17^{\mathrm{b}}$ & 0.05 \\
True N & 4.89 & $4.88^{\mathrm{a}}$ & 4.87 & 4.80 & 0.07 \\
Casein N & $3.82^{\mathrm{b}}$ & $3.91^{\mathrm{a}}$ & $3.90^{\mathrm{a}}$ & $3.94^{\mathrm{a}}$ & 0.06 \\
Whey N & 1.07 & 0.97 & 0.97 & 0.96 & 0.08 \\
NPN & 0.39 & 0.37 & 0.40 & 0.37 & 0.05 \\
True N, as \% total N & 92.61 & 92.95 & 92.41 & 92.84 & 0.59 \\
Casein N, as \% total N & $72.35^{\mathrm{cC}}$ & $74.48^{\mathrm{bB}}$ & $74.00^{\mathrm{bB}}$ & $76.21^{\mathrm{aA}}$ & 1.33 \\
NPN, as \% total N & 7.39 & 7.05 & 7.59 & 7.16 & 0.60 \\
\hline
\end{tabular}

RPO - rapeseed oil, LIO - linseed oil, SYO - soyabean oil, SFO - sunflower oil a,b,c - values in the same rows with different letters differ significantly $(\mathrm{P}<0.05)$

$\mathrm{A}, \mathrm{B}, \mathrm{C}-$ values in the same rows with different letters differ significantly $(\mathrm{P}<0.01)$ 
The basic fatty acid profile of milk was typical for the milk of Red-andWhite cows (Table 5). Saturated acids dominated among the fatty acids, with myristic, palmitic, and stearic acids $\left(\mathrm{C}_{14: 0,}, \mathrm{C}_{16: 0,}, \mathrm{C}_{18: 0}\right)$ accounting for about $59 \mathrm{~g} / 100 \mathrm{~g}$ of fatty acids. No significant differences were found among the groups of cows in the contents of short- and medium-chain fatty acids or of mono-, di, and tri-unsaturated fatty acids. Feeding rapeseed and sunflower oils to cows significantly $(\mathrm{P}<0.01)$ increased the content of conjugated CLA in milk.

TABLE 5

Fatty acid composition of milk fat, $\mathrm{g} / 100 \mathrm{~g}$

\begin{tabular}{|c|c|c|c|c|c|}
\hline \multirow{2}{*}{ Item } & \multicolumn{4}{|c|}{ Plant oils } & \multirow{2}{*}{$\mathrm{SE}$} \\
\hline & RPO & LIO & SYO & SFO & \\
\hline $\mathrm{C}_{8 \cdot 0}$ & 2.29 & 2.38 & 2.49 & 2.21 & 0.08 \\
\hline$C_{10: 0}^{8: 0}$ & 4.07 & 4.04 & 4.41 & 3.84 & 0.14 \\
\hline $\mathrm{C}_{12.0}^{100}$ & 4.55 & 4.37 & 4.87 & 4.32 & 0.14 \\
\hline $\mathrm{C}_{14 \cdot 0}$ & 13.99 & 13.85 & 14.27 & 13.34 & 0.21 \\
\hline $\mathrm{C}_{16: 0}^{140}$ & 34.63 & 35.33 & 35.32 & 34.88 & 0.51 \\
\hline$C_{16: 1}^{16: 0}$ & 1.96 & 1.95 & 1.76 & 1.97 & 0.10 \\
\hline$C_{18: 0}^{16: 0}$ & 9.86 & 10.38 & 9.70 & 9.99 & 0.34 \\
\hline$C_{18: 1}^{18.0}$ & 23.18 & 22.96 & 22.08 & 23.99 & 0.55 \\
\hline$C_{18: 0}^{18: 2}$ & 3.48 & 3.16 & 3.28 & 3.45 & 0.09 \\
\hline $\mathrm{C}_{18.3 \mathrm{GAMMA}}^{18.2}$ & 0.073 & 0.080 & 0.078 & 0.070 & 0.003 \\
\hline $\mathrm{C}_{18: 3 \text { ALFA }}$ & 0.423 & 0.357 & 0.347 & 0.400 & 0.017 \\
\hline CLA & $1.212^{\mathrm{Aa}}$ & $1.015^{\mathrm{cC}}$ & $1.092^{\mathrm{bB}}$ & $1.238^{\mathrm{aA}}$ & 0.049 \\
\hline $\operatorname{CLA} c 9-t 11$ & $0.970^{\mathrm{bB}}$ & $0.814 \mathrm{dD}$ & $0.902^{\mathrm{cC}}$ & $1.055^{\mathrm{aA}}$ & 0.042 \\
\hline CLA $t 10-c 12$ & $0.047^{\mathrm{a}}$ & $0.027^{b}$ & $0.022^{\mathrm{b}}$ & $0.044^{\mathrm{a}}$ & 0.005 \\
\hline CLA & 0.035 & 0.030 & 0.040 & 0.040 & 0.003 \\
\hline CLA $t 9-t 11$ & 0.142 & 0.122 & 0.123 & 0.138 & 0.009 \\
\hline $\mathrm{C}_{20 \cdot 0}$ & 0.097 & 0.114 & 0.027 & 0.103 & 0.006 \\
\hline $\mathrm{C}_{20: 5}^{2.0}$ EPA & 0.029 & 0.028 & 0.023 & 0.027 & 0.001 \\
\hline $\mathrm{C}_{2 \cdot 0}^{20.0}$ & 0.022 & 0.026 & 0.027 & 0.027 & 0.003 \\
\hline $\mathrm{C}_{222.4}^{22.0} \mathrm{AA}$ & 0.123 & 0.124 & 0.123 & 0.126 & 0.004 \\
\hline SFA & 69.51 & 70.49 & 71.21 & 68.72 & 0.64 \\
\hline UFA & 30.49 & 29.51 & 28.79 & 31.28 & 0.64 \\
\hline MUFA & 25.15 & 24.73 & 23.85 & 25.96 & 0.56 \\
\hline PUFA & 5.35 & 4.78 & 4.94 & 5.31 & 0.13 \\
\hline PUFA-6 & 3.67 & 3.37 & 3.48 & 3.64 & 0.09 \\
\hline PUFA-3 & 0.46 & 0.39 & 0.37 & 0.44 & 0.02 \\
\hline DFA $^{1}$ & 40.35 & 39.89 & 38.49 & 41.28 & 0.80 \\
\hline $\mathrm{OFA}^{2}$ & 59.65 & 60.11 & 61.51 & 58.73 & 0.80 \\
\hline UFA/SFA & 0.44 & 0.43 & 0.41 & 0.46 & 0.01 \\
\hline DFA/OFA & 0.69 & 0.68 & 0.65 & 0.73 & 0.02 \\
\hline MUFA/SFA & 0.37 & 0.36 & 0.34 & 0.39 & 0.01 \\
\hline PUFA/SFA & 0.08 & 0.07 & 0.07 & 0.08 & 0.00 \\
\hline PUFA $6 / 3$ & 8.65 & 8.89 & 9.66 & 9.33 & 0.34 \\
\hline
\end{tabular}

RPO - rapeseed oil, LIO - linseed oil, SYO - soyabean oil, SFO - sunflower oil, DFA ${ }^{1}$ - desirable fatty acids, $\mathrm{OFA}^{2}$ - undesirable fatty acids, ${ }^{\mathrm{a}, \mathrm{b}, \mathrm{c}, \mathrm{d}}$ - values in the same rows with different letters differ significantly $(\mathrm{P}<0.05),{ }^{A}, \mathrm{~B}, \mathrm{C}, \mathrm{D}$ - values in the same rows with different letters differ significantly $(\mathrm{P}<0.01)$ 
Significant differences were found in the content of cis -9, trans-11 CLA isomers: the highest concentration was in the milk of cows receiving sunflower oil, the lowest, in those given linseed oil. The difference in relative amounts came to $29.6 \%$. The content of the cis-9 trans-11 CLA isomer in milk amounted to $82.1 \%$ of the total CLA content of milk, with the remaining isomers, including trans-10 cis-12, cis-9 cis-11 and trans-9 trans-11, accounting for 3.1; 3.2, and 11.5\%, respectfully, of the total amount of CLA; the differences in their contents were not significant.

No significant differences were found in the content of long-chain fatty acids in milk (including eicosapentaenoic, $\mathrm{C}_{20: 5}, \mathrm{n}-3$, EPA, and arachidonic $\left(\mathrm{C}_{20: 4}, \mathrm{n}-6\right.$, AA) acids), total saturated fatty acids (SFA) and unsaturated fatty acids (UFA), as well as polyunsaturated fatty acids (PUFA).

The saturated fatty acid content in cow's milk came to about $70 \mathrm{~g} / 100 \mathrm{~g}$, that of monounsaturated fatty acids (MUFA), to about $25 \mathrm{~g} / 100 \mathrm{~g}$.

Supplementing rations with soyabean oil significantly $(\mathrm{P}<0.01)$ lowered the production of medium-chain fatty acids, while adding soyabean and sunflower oils decreased production of long-chain fatty acids (Table 6). The production of

TABLE 6

Calculated yields of milk fatty acid, $\mathrm{g} / \mathrm{d}$

\begin{tabular}{|c|c|c|c|c|c|}
\hline \multirow{2}{*}{ Item } & \multicolumn{4}{|c|}{ Plant oils } & \multirow{2}{*}{ SE } \\
\hline & RPO & LIO & SYO & SFO & \\
\hline Total fatty acids & 857.0 & 854.0 & 818.0 & 818.0 & 10.2 \\
\hline Short-chain fatty acids & 93.5 & 92.1 & 96.3 & 84.8 & 4.1 \\
\hline Medium-chain fatty acids & $433.5^{\mathrm{Aa}}$ & $435.3^{\mathrm{Aa}}$ & $405.9^{\mathrm{bB}}$ & $410.5^{\mathrm{bB}}$ & 8.4 \\
\hline Long-chain fatty acids & $330.0^{\mathrm{aA}}$ & $326.6^{\mathrm{aA}}$ & $300.8^{\mathrm{bB}}$ & $322.4^{\mathrm{aA}}$ & 10.5 \\
\hline CLA & $10.37^{\mathrm{aA}}$ & $8.67^{\mathrm{bB}}$ & $8.93^{\mathrm{bB}}$ & $10.1^{\mathrm{aA}}$ & 0.52 \\
\hline CLA $c 9 t 11$ & $8.31^{\mathrm{aA}}$ & $6.95^{\mathrm{bB}}$ & $7.38^{\mathrm{bB}}$ & $8.63^{\mathrm{aA}}$ & 0.44 \\
\hline CLA $t 10 c 12$ & 0.40 & 0.23 & 0.18 & 0.36 & 0.05 \\
\hline CLA & 0.30 & 0.26 & 0.33 & 0.33 & 0.04 \\
\hline CLA $t 9 t 11$ & 1.22 & 1.04 & 1.01 & 1.13 & 0.09 \\
\hline $\mathrm{C}_{2} \mathrm{EPA}$ & 0.25 & 0.24 & 0.19 & 0.22 & 0.01 \\
\hline $\mathrm{C}_{20.4}^{20.5} \mathrm{AA}$ & 1.05 & 1.06 & 1.01 & 1.03 & 0.04 \\
\hline SFA & $595.7^{\mathrm{AA}}$ & $602.0^{\mathrm{aA}}$ & $582.5^{\mathrm{aA}}$ & $562.1^{\mathrm{bB}}$ & 6.7 \\
\hline UFA & $261.3^{\mathrm{aA}}$ & $252.0^{\mathrm{aA}}$ & $235.5^{\mathrm{bB}}$ & $255.9^{\mathrm{aA}}$ & 6.7 \\
\hline MUFA & $215.5^{\mathrm{a}}$ & $211.2^{\mathrm{a}}$ & $195.1^{\mathrm{b}}$ & $212.4^{\mathrm{a}}$ & 5.8 \\
\hline PUFA & 45.8 & 40.8 & 40.4 & 43.4 & 1.4 \\
\hline PUFA-6 & 31.5 & 28.8 & 28.5 & 29.8 & 0.7 \\
\hline PUFA-3 & 3.9 & 3.3 & 3.0 & 3.6 & 0.3 \\
\hline DFA $^{1}$ & $345.8^{\mathrm{aA}}$ & $340.7^{\mathrm{aA}}$ & $314.8^{\mathrm{bB}}$ & $337.6^{\mathrm{aA}}$ & 8.5 \\
\hline $\mathrm{OFA}^{2}$ & $511.2^{\mathrm{aA}}$ & $513.3^{\mathrm{Aa}}$ & $503.2^{\mathrm{aA}}$ & $480.4^{\mathrm{bB}}$ & 8.5 \\
\hline
\end{tabular}

RPO - rapeseed oil, LIO - linseed oil, SYO - soyabean oil, SFO - sunflower oil, , DFA ${ }^{1}$ - desirable fatty acids, OFA ${ }^{2}$ - undesirable fatty acids, a,b - values in the same rows with different letters differ significantly $(\mathrm{P}<0.05),{ }^{\mathrm{A}, \mathrm{B}}$ - values in the same rows with different letters differ significantly $(\mathrm{P}<0.01)$ 
CLA, including its cis-9 trans- 11 isomer, was the lowest in cows receiving sunflower and rapeseed oils, whereas the content of the remaining CLA isomers did not differ significantly among groups. The production of unsaturated fatty acids in milk was significantly lower when cows were fed soyabean oil $(\mathrm{P}<0.01)$ in comparison with the remaining oils, but PUFA production remained unchanged. Significantly lower production of fatty acids having hypocholesterolaemic properties was found in cows fed soyabean oil $(\mathrm{P}<0.01)$.

The differences in blood plasma parameters (glucose content, total protein, lipids, triglycerides, cholesterol and the lipoprotein fractions HDL and LDL) in cows given vegetable oils were not significant (Table 7).

TABLE 7

Metabolite level in the blood plasma

\begin{tabular}{lrrrrr}
\hline \multirow{2}{*}{ Item } & \multicolumn{4}{c}{ Plant oils } & \multirow{2}{*}{ SE } \\
\cline { 2 - 5 } & \multicolumn{1}{c}{ RPO } & \multicolumn{1}{c}{ LIO } & \multicolumn{1}{c}{ SYO } & \multicolumn{1}{c}{ SFO } & \\
\hline Glucose, $\mathrm{mg} / 100 \mathrm{ml}$ & 71.82 & 70.20 & 65.28 & 71.10 & 3.05 \\
Total protein, $\mathrm{mg} / 100 \mathrm{ml}$ & 8.21 & 8.25 & 8.26 & 8.13 & 0.08 \\
Total lipids, $\mathrm{mg} / 100 \mathrm{ml}$ & 343.41 & 359.54 & 320.41 & 326.36 & 11.27 \\
Triglycerides, $\mathrm{mg} / 100 \mathrm{ml}$ & 5.83 & 5.79 & 5.34 & 5.27 & 0.18 \\
Total cholesterol, $\mathrm{mg} / 100 \mathrm{ml}$ & 195.63 & 190.96 & 177.09 & 179.37 & 4.99 \\
HDL, $\mathrm{mg} / 100 \mathrm{ml}$ & 169.03 & 164.78 & 155.59 & 155.93 & 1.48 \\
LDL, $\mathrm{mg} / 100 \mathrm{ml}$ & $27.78^{\mathrm{a}}$ & $25.59^{\mathrm{a}}$ & $21.84^{\text {ab }}$ & $19.22^{\mathrm{b}}$ & 0.05 \\
\hline
\end{tabular}

RPO - rape oil, LIO - linseed oil, SYO - soyabean oil, SFO - sunflower oil

a,b - values in the same rows with different letters differ significantly $(\mathrm{P}<0.05)$

\section{DISCUSSION}

Studies carried out to date point to the anti-cancer effects of CLA, its properties as an immune modulator, its anti-diabetic actions and reduction of atherogenesis (Parodi, 1997). CLA in milk comes mainly from endogenous synthesis (from 61 to $78 \%$ ) in which the enzyme, $\Delta 9$ desaturase, plays a role (Griinari et al., 2000), the remaining part comes from the rumen, taken up directly from the bloodstream and lipoproteins transporting fatty acids to the mammary gland (Corl et al., 2000; Griinari et al., 2000). In the rumen, CLA is an intermediate in the process of hydrogenating unsaturated fatty acids, mainly linoleic and $\alpha$-linolenic acids, by rumen bacteria (Kepler and Tove, 1967). According to Doreau and Ferley (1994) the extent of hydrogenation of fatty acids in the rumen is very high and comes to about $85-100 \%$ for linoleic acid, and $70-85 \%$ for linolenic acid.

The vegetable oils used in this study differ in their fatty acid compositions. The dominant fat in rapeseed oil is oleic acid $\left(\mathrm{C}_{18: 1}\right)$, in linseed oil, linolenic acid $\left(\mathrm{C}_{18: 3}\right)$, 
whereas in soyabean and sunflower oils, linoleic acid $\left(\mathrm{C}_{18: 2}\right)$. Hence the MUFA/ SFA, PUFA/SFA and MUFA/PUFA ratios in these oils differ.

The results of this study indicate that feeding cows vegetable oils in amounts equivalent to about $1.5 \%$ of the ration's dry matter content $(320 \mathrm{~g} / \mathrm{d})$ did not negatively affect milk yield or the basic traits of milk (acidity, density, and specific gravity). No significant differences were found either in milk protein production efficiency or the ratio of protein digested in the small intestine to the net energy of milk (PDI/NEL).

Depending on the type of added oils, which differed in their saturated fatty acid content, the CLA content of milk differed significantly; its content in the milk of cows fed sunflower or rapeseed oils was about $16 \%$ higher than in cows given linseed and soyabean oils. It can, therefore, be supposed that the fatty acids in both of these oils were hydrogenated to a high extent, including transvaccenic acid $\left(\mathrm{C}_{18: 1}\right.$ trans-11, TVA), which is considered to be the main substrate for the endogenous synthesis of CLA $\left(\mathrm{C}_{18: 2}\right.$ cis-9 trans-11) (Wonsil et al., 1994; Salminen et al., 1998).

It was shown that the cis-9, trans -11 isomers of $\mathrm{C}_{18: 2}$ acid account for about 90\% of the total CLA (Griinari and Bauman, 1999; Parodii, 1999). We found lower values in our study. An increase in the content of $\mathrm{C}_{18: 2}$ cis-9 trans-11 CLA and transvaccenic acid $\mathrm{C}_{18: 1}$ trans-11 was obtained in the milk of cows receiving fish oil supplements, extruded soyabeans, or their mixture (AbuGhazaleh et al., 2002).

On the basis of studies carried out to date the consensus is that the most effective way of increasing the content of CLA isomers in milk is to give lactating cows and goats a mixture of polyunsaturated fish oil or mixtures of other oils (Whitlock et al., 2002; Lock and Garnsworthy, 2002; Szumacher-Strabel, 2005). Ramaswamy et al. (2001) fed cows fish oil ( $2.0 \%$ of the ration's dry matter), extruded soyabeans (10.6\%) and a mixture of both products and found 1.2-2.2 g CLA cis-9 trans-11/100 g of fatty acids in the milk of these cows. Baer et al. (2001) gave cows fish oil in an amount equivalent to $2.0 \%$ of the ration's dry matter and obtained $2.4 \mathrm{~g} / 100 \mathrm{~g}$ fat of CLA cis-9 trans- 11 isomer in comparison with $0.7 \mathrm{~g} / 100 \mathrm{~g}$ in control rations.

White et al. (2001) found variability among breeds in the CLA content of cow's milk, which shows that the ability to synthesize CLA is highly dependent on genetic traits, and also showed that the milk of grazing Holstein and Jersey cows contained about $0.7 \%$ and $0.6 \mathrm{~g}$ CLA/ $100 \mathrm{~g}$ fatty acids, respectively. It was also found that grazing in comparison with confined feeding increases the CLA content in milk by about $45 \%$. The content of CLA isomers drops rapidly when switching from grazing to feeding silage in the winter. The studies conducted by Elgersma et al. (2004) show that within 14 days from ending grazing the content of cis-9 trans- 
11 CLA isomers in milk fell from 2.30 to $0.37 \mathrm{~g} / 100 \mathrm{~g}$ fatty acids. The results of our study indicate that at a level of about 1.0-1.2 g total CLA/100 g fatty acids, the daily production of CLA equaled about $8.8-10.5 \mathrm{~g} / \mathrm{cow}$. The respective values for the $\mathrm{C}_{18: 2}$ cis-9 trans-11 isomer were about 7.0-8.6 $\mathrm{g}$, at an average production of $952 \mathrm{~g}$ fat/day and $838 \mathrm{~g}$ fatty acids /day. On the basis of the studies conducted to date it can be said that the extreme values of CLA content in the milk of cows range from 0.3 to $0.6 \mathrm{~g} / 100 \mathrm{~g}$ fat in cows that do not receive vegetable or fish oils to $1.0-2.5 \mathrm{~g} / 100 \mathrm{~g}$ fat when oil seeds or moderate amounts of fish or vegetable oils are fed, or when the cows are pasture fed.

The amounts of CLA possible to obtain in milk given above are far from the amounts showing therapeutic activity. Wiliams (2000) reports that humans need 3.0-3.5 g/d of CLA in their diets to achieve an anti-cancer effect and 15-20 g/day to inhibit lipogenesis and fat deposition. This is about $0.04 \mathrm{~g} / \mathrm{kg}$ body weight and $0.05 \%$ of a diet. These are amounts that would be difficult to obtain in cow's milk by feeding the animals in a way promoting the synthesis of CLA isomers and their excretion into milk.

A relatively high content of long-chain fatty acids, eicosapentaenoic (EPA) and arachidonic (AA), was found in the cows' milk, but the differences between the groups of cows and the oils used in their diets were not significant. EPA and DHA belong to the $\omega-3$ family and are synthesized by the animals from linoleic and linolenic acids in a process catalysed by the enzymes $\Delta^{5}$ and $\Delta^{6}$ desaturase, which increase the number of double bonds, as well as by elongase, which is responsible for lengthening the fatty acid carbon chain (Givens et al., 2000). Both of these acids, as well as arachidonic acid (AA) found in the milk of cows, make up eicosanoids which are classified as tissue hormones, from which prostaglandins, leukotrienes and thromboxanes are synthesized in the bodies of people who drink milk. These substances lower blood pressure and exhibit anti-inflammatory, anti-thrombotic and anti-atherosclerotic properties (Bartnikowska and Kulasek, 1994).

Adding vegetable oils to diets for cows did not lead to an increase in total unsaturated fatty acids in milk, in contrast to cows given rations containing rumen-protected fatty acid calcium salts (Aii et al., 1991; Brzóska et al., 1999 a,b). This confirms the opinion that nearly the entire unsaturated fatty acid content of vegetable oils undergoes hydrogenation in the rumen and is not transported directly to the mammary gland in the form of protein-bound unsaturated fatty acids, i.e. lipoproteins. This conclusion is supported by in vitro studies (Gulati et al., 2000). A comparison of the fatty acid profiles of cows from the same herd (Brzóska et al., 1999 b) showed that feeding vegetable oils distinctly increased the content of palmitic oil $\left(\mathrm{C}_{16: 0}\right)$, as well as that of oleic, linoleic, including CLA $\left(\mathrm{C}_{18: 2}\right)$ and linolenic acids. Total unsaturated fatty acids 
and stearic acid $\left(\mathrm{C}_{18: 0}\right)$ were higher in the control group of cows that did not received a fat-supplemented diet.

Feeding cows vegetable oil did not cause significant changes in blood plasma parameters. The glucose, total protein, total lipid and triglyceride levels were within normal physiological ranges (Kłopocki and Winnicka, 1992). This indicates that the addition of vegetable oils to diets did not change the metabolism of carbohydrates, protein or fat, whereas it distinctly lowered the blood cholesterol level (Brzóska et al., 1999 a,b). The addition of soyabean and sunflower oil significantly reduced total cholesterol and lipoprotein LDL. These results support the previously shown negative correlation between the level of unsaturated fatty acids in the diet and the synthesis of endogenous cholesterol in the liver of cows.

In summary, it can be said that feeding vegetable oils in an amount equivalent to about $1.5 \%$ of the ration's dry matter content $(320 \mathrm{~g} / \mathrm{d})$ to cows characterized by a daily yield of about $25 \mathrm{~kg}$ of milk does not affect the content of saturated and unsaturated fatty acids in milk, but does increase the content of total CLA isomers to $1.0-1.2 \mathrm{~g} / 100$ $\mathrm{g}$ fatty acids and of its cis-9, trans- 11 isomer to $0.80-1.05 \mathrm{~g} / 100 \mathrm{~g}$ fatty acids in milk. This corresponds to a daily synthesis of both of these compounds in amounts of 8.7$10.4 \mathrm{~g}$ (CLA), respectively, and 7.0-8.6 g/cow (CLA cis-9, trans-11).

Vegetable oils added to rations in this amount do not cause significant differences in milk yield, basic milk traits, and metabolic parameters of blood plasma, maintaining total cholesterol and LDL at levels considered low for cattle.

\section{ACKNOWLEDGEMENTS}

The author wishes to thank Ms Bogusława Barteczko-Midor for caring for the animals and taking samples of feeds and milk as well as for conducting some of the analyses. The author also wishes to thank the employees of the Central Laboratory of the National Research Institute of Animal Production, Marta Szczypuła, M.Sc., Krystyna Sala, Ph.D., Marek Kryszczak, M.Sc., Alicja Sobczyk and Zdzisław Czmer for performing the chemical analyses of feeds and milk.

\section{REFERENCES}

AbuGhazaleh A.A., Schingoethe D.J., Hippen A.R., Kalscheur K.F., 2002. Feeding fish meal and extruded soybeans enhances the conjugated linoleic acid (CLA) content of milk. J. Dairy Sci. $85,624-631$

Aii T., Kurihara M., Ishida S., 1991. Increase in $\alpha$-linoleic acid in milk fat by feeding the calcium soap of fatty acids prepared from linseed oil. Anim. Sci. Tech. 62, 58-62

Atwal A.S., Hidiroglou M., Kramer J.K.G., Binns M.R., 1990. Manipulation of the fatty acids composition of milk by feeding protected canola seeds. J. Dairy Sci. 75, 1090-1096 
Baer R.J., Ryali J., Schingoethe D.J., Kasperson K.M., Donovan D.C., Hippen A.R., Franklin S.T., 2001. Composition and properties of milk and butter from cows fed fish oil. J. Dairy Sci. 84, 345-353

Bartnikowska E., Kulasek G., 1994. Importance of unsaturated fatty acids in human and animal nutrition. Second Part. (in Polish). Med. wet. 3, 34-38

Brzóska F., Gąsior R., Sala K., Wiewióra W., 1999a. Effect of calcium salts of fatty acids from animal fat, rape oil, linseed oil and fish oil on the yield and composition of cows milk. Ann. Anim. Sci. 26 (2), 105-117

Brzóska F., Gąsior R., Sala K., Zyzak W., 1999b. Effect of linseed oil fatty acid calcium salts and vitamin $\mathrm{E}$ on milk yield and composition. J. Anim. Feed Sci. 8, 367-378

Corl B.A., Baumgard L.H., Dwyer D.A., Griinari J.M., Phillips B.S., Bauman D.E., 2000, The role of delta 9 desaturase in the production of cis 9, trans 11 CLA and other delta saturated fatty acids in milk fat. J. Anim. Sci. 78, Suppl. 1, 164 (Abstr.)

Dhiman T.R., Anand G.R., Satter L.D., Pariza M.W., 1999. Conjugated linoleic acid content of milk from cows fed different diets. J. Dairy Sci. 82, 2146-2156

Doreau M., Ferley A., 1994. Digestion and utilization of fatty acid by ruminants. Anim. Feed Sci. Tech. 45, 379-396

Elgersma A., Ellen G., van der Horst H., Boer H., Dekker P.R., Tamminga S., 2004. Quick changes in milk fat composition from cows after transition from fresh grass to a silage diet. Anim. Feed Sci.Tech. 117, 13-27

Folch J., Lees M., Sloane-Stanley G.H. 1956. A simple method for the isolation and purification of total lipids from animal tissues. J. Biol. Chem. 226, 497-509

Givens D.I., Cottrill B.R., Davies M., Lee P.A., Mansbridge R.J., Moss A.R., 2000. Sources of n-3 polyunsaturated fatty acids additional to fish oil for livestock diets - a review. Nutr. Abstr. Rev. $70,1-19$

Goering H.R., van Soest P.J., 1970. Forage Fiber Analysis. Agriculture Handbook, No. 379. USDA, Washington

Gordon W.G., Kolan E.B., 1983. Proteins in milk. In: Fundamentals of Dairy Chemistry. $2^{\text {nd }}$ Edition. B.H. Webb, A.H. Johnson, J.A. Alford (Editors). AVI Publ. Co., Inc., West Port, CT, pp. 78

Griinari J.M., Baumann D.E., 1999. Biosynthesis of conjugated linoleic acid and its incorporation into meat and milk in ruminants. In: M.P. Yurawecz, M.M. Mossaba, J.K.G. Kramer, M.W. Pariza, G.J. Nelson (Editors). Advances in Conjugated Linoleic Acid Research. Vol. II, Champaign, Illinois: AOAC Press, pp. 180-200

Griinari J.M., Corl B.A., Lacy S.H., Chouinard P.Y., Nurmela K.V.M., Baumann D.E., 2000. Conjugated linolenic acid is synthetized endogenously in lactating dairy cows by delta 9desaturase. J. Nutr. 130, 2285-2291

Gulati S.K., Kitessa S.M., Ashes J.R., Fleck E., Byers E.B., Buers Y.G., Scott T.W., 2000. Protection of conjugated liloleic acid from ruminal hydrogenation and their incorporation into milk fat. Anim. Feed Sci. Tech. 86, 139-148

Kalscheur K.F., Teter B.B., Piperova L.S., Erdman R.A., 1997. Effect of fat source on duadenal flow of trans-C18:1 fatty acids and milk fat production in dairy cows. J. Dairy Sci. 80, 2115-2126

Kelly M.L., Kolver E.S., Bauman D.E., van Amburgh M.E., Muller L.D., 1998. Effect of intake of pasture on concentrations of conjugated linoleic acid in milk of lactating cows. J. Dairy Sci. 81, $1630-1636$

Kepler C.R., Tove S.B., 1967. Biohydrogenation of unsaturated fatty acids. J. Biol. Chem. 242, 5686-5692

Kłopocki T., Winnicka A., 1992. Right Basic Values of Laboratory Assays (in Polish). $2^{\text {nd }}$ Edition. University of Agriculture (SGGW) pRESS. Warszawa 
Lipkowski A.W., Walisiewicz-Niedbalska W., Patkowska Sokoła B., Opolski A., Bodkowski R., Wietrzyk J., Pełczyńska M., Nasulewicz A., Gwardiak H., Kwiatkowski J., 2003. In vitro anticancer properties of natural vs synthetic conjugated linoleic acid. Anim. Sci. Pap. Rep. 21, 47-55

Lipski S., Machul M., Brzóska F., Kęsik K., Górski T., Madej A., 2002. Maize for silage production from whole plants (in Polish). Agricultural Handbook No. 90/02. Edited: Institute of Soil Science and Plant Cultivation Puławy, National Research Institute of Animal Production, Kraków (in Polish)

Lock A.L., Garnsworthy P.C., 2002. Independent effects of dietary linoleic and linolenic fatty acids on the conjugated linoleic acid content of cows milk. Anim. Sci. 74, 163-176

MRiRW, 2003. Analytic assays instructions recommended for nutrient and additives estimation in material feeds, premixes and concentrates (in Polish). Edited: Ministry of Agriculture and Rural Development. Official Gazette Announcing Current Legislation. 17 April 2003

National Research Council, 1996. Carcinogens and Anticarcinogens in the Human Diet. National Academy of Science, Washington, DC

Noone E.J., Roche H.M., Nugent A.P., Gibney M.J., 2002. The effect of dietary supplementation using isomeric blends of conjugated linoleic acid on lipid metabolism in healthy human subjects. Brit. J. Nutr. 88, 243-251

Parodi P.W., 1997. Cows milk fat components as potencial anticarcinogenic agents. J. Nutr. 127, 1055-1060

Parodi P.W., 1999. Conjugated linoleic acid and ther anticarcinogenic agents of bovine milk fat. J. Dairy Sci. 82, 1339-1349

Polska Norma (Polish Standards) PN 68/A-86122. Milk. Methods of Investigation (in Polish). Polish Committee of Standarization, Warszawa (Poland)

Polska Norma (Polish Standards) PN-76/R-64781. Feeds. Phosphorus estimation (in Polish). Polish Committee of Standarization, Warszawa (Poland)

Ramaswanny N., Baer R.J., Schingoethe D.J., Hippen A.R., Kasperson K.M., Whitlock L.A., 2001. Composition and flavor of milk and butter from cows fed fish oil, extruded soybeans, or their combinations. J. Dairy Sci. 84, 2144-2151

Salminen I., Mutanen M., Jauhiainene M., Aro A., 1998. Dietary trans fatty acids increase conjugated linoleic acid levels in human serum. Nutr. Biochem. 9, 93-98

SCSGN, 2001. Standards for Cattle, Sheep and Goats Nutrition. Nutrition Value of Feeds for Ruminants (in Polish). Edited: National Research Institute of Animal Production, Kraków

Steinhart C., 1996. Conjugated linoleic acid-the good news about animal fat. J. Chem. Educ. 73, A302-A303

Subnel A.P.J., Meijer R.G.M., Van Straalen W.M., Tamminga S., 1994. Efficiency of milk protein production in the DVE protein evaluation system. Livest. Prod. Sci. 40, 215-224

Szumacher-Strabel M., 2005. Effect of fat additives to sheep and goat daily rations on unsaturated fatty acids content in the rumen fluid and milk, especially isomers of CLA (in Polish). Editor: The August Cieszkowski Agricultural University of Poznań. Dissertation, pp. 1-20

Thomas P.C., Chamberlain D.G., 1984. Manipulation of milk composition to meet market needs. In: Recent Advances Animal Nutrition, pp. 219-243

White S.L., Bertrand J.A., Wade M.R., Weshburn S.P., Green Jr. J.T., Jenkins T.C., 2001. Comparison of fatty acid content of milk from Jersey and Holstein cows consuming pasture or total mixed ration. J. Dairy Sci. 84, 2295-2301

Whitlock L.A., Schingoethe D.J., Hippen A.R., Kalscheur K.F., Baer R.J., Ramaswamy N., Kasperson K.M., 2002. Fish oil and extruded soybeans fed in combination increase conjugated linoleic acid in milk of dairy cows more than fed separately. J. Dairy Sci. 85, 234-243

Williams C.M., 2000. Dietary fatty acids and human health. Ann. Zootech. 49, 165-180 
Wonsil B.J., Herbein J.J., Watkins B.A., 1994. Dietary and ruminally derived trans-18:1 fatty acids alter bovine milk lipids. J. Nutr. 124, 556-565

\section{STRESZCZENIE}

\section{Wpływ olejów roślinnych na wydajność krów, skład mleka i zawartość CLA w mleku}

Celem badań było określenie wpływu podawania krowom olei roślinnych na zawartość nienasyconych kwasów tłuszczowych w mleku, w tym izomerów kwasu CLA. Doświadczenie wykonano na 16 krowach rasy czb, w układzie 4 x 4 kwadratu łacińskiego. Krowy podzielono na 4 grupy i żywiono dawkami zawierającymi kiszonkę z traw, kiszonkę z kukurydzy, młóto browarniane i mieszankę treściwą. Oleje roślinne w ilości 1,5\% pobrania suchej masy $(320 \mathrm{~g} / \mathrm{d})$ podawano na nośniku z otrąb pszennych.

Nie stwierdzono istotnych różnic w wydajności mlecznej krów i ilości mleka standaryzowanego na zawartości thuszczu i białka (FPCM). Podawanie krowom oleju lnianego istotnie zwiększyło zawartość tłuszczu w mleku, natomiast oleju słonecznikowego istotnie go obniżyło. Krowy otrzymujące olej rzepakowy i lniany produkowały najwięcej tluszczu w cyklach dobowych. Nie stwierdzono istotnych różnic w procentowej zawartości białka oraz cechach mleka, jak kwasowość, krzepliwość i gęstość.

Zawartość $\mathrm{N}$ kazeinowego była istotnie mniejsza u krów otrzymujących olej rzepakowy. Najwyższy udział N kazeinowego w N ogólnym stwierdzono w mleku krów otrzymujących olej słonecznikowy.

Podawanie krowom oleju rzepakowego i słonecznikowego istotnie zwiększyło zawartość sumy izomerów kwasu CLA w mleku, średnio o 16\%. Najwyższą zawartość izomerów cis-9 trans-11 CLA stwierdzono w mleku krów otrzymujących olej słonecznikowy, a najniższą w mleku krów otrzymujących olej lniany. Dobowa produkcja CLA cis-9 trans-11 w mleku w cyklach dobowych wynosiła 8,8-10,5 $\mathrm{g} / \mathrm{d}$ i była istotnie wyższa przy podawaniu krowom oleju słonecznikowego i rzepakowego. Zawartość kwasów nasyconych w mleku krów wynosiła około $70 \mathrm{~g} / 100 \mathrm{~g}$, a jednonienasyconych (MUFA) około $25 \mathrm{~g} / 100 \mathrm{~g}$. Nie stwierdzono istotnych różnic w parametrach osocza krwi krów otrzymujących oleje roślinne, w tym zawartości glukozy, białka całkowitego, lipidów, trójglicerydów i cholesterolu całkowitego, przy spadku istotnym zawartości LDL u krów otrzymujących olej sojowy i słonecznikowy. 